\title{
Pengaruh Jenis Katalis pada Elektroda Pembanding terhadap Efisiensi Dye Sensitized Solar Cells dengan Klorofil sebagai Dye Sensitizer
}

\author{
Nurrisma Puspitasari, ${ }^{*}$ Siti Rabiatul Adawiyah, Muhammad Noer Fajar, Gatut Yudoyono, Agus Rubiyanto, dan Endarko \\ Jurusan Fisika- FMIPA, Institut Teknologi Sepuluh Nopember, Kampus ITS Sukolilo, Surabaya 60111

\section{Intisari} \\ Dye Sensitized Solar Cell (DSSC) merupakan sel surya tersensitisasi zat pewarna yang dibentuk dengan \\ struktur sandwich dimana terdapat lima bagian antara lain: kaca ITO (Indium Tin Oxide) sebagai substrat; $\mathrm{TiO}_{2}$ \\ sebagai bahan semikonduktor; dye klorofil sebagai donor elektron; elektrolit sebagai transfer elektron. Ser- \\ buk $\mathrm{TiO}_{2}$ berukuran nanometer didapatkan melalui sintesis dengan metode kopresipitasi.Pengukuran dilakukan \\ pada daya $100 \mathrm{~mW} / \mathrm{cm}^{2}$. Hasil efisiensi DSSC menggunakan active carbon sebagai katalis pada elektroda pem- \\ banding menghasilkan prosentase yang lebih besar daripada black carbon dan grafit, yaitu $0,05 \%$ untuk active \\ carbon, 0,032\% untuk black carbon, 0,029\% untuk grafit.
}

\section{ABSTRACT}

Dye-sensitized Solar Cell (DSSC) is a dye sensitized solar cells are formed by a sandwich structure where there are five parts include: glass ITO (Indium Tin Oxide) as a substrate; $\mathrm{TiO}_{2}$ as a semiconductor material; chlorophyll dye as an electron donor; electrolyte as electron transfer. Nanometer-sized $\mathrm{TiO}_{2}$ powder obtained through synthesis by coprecipitation method. Measurements were taken at the power of $100 \mathrm{~mW} / \mathrm{cm}^{2}$. The results of the efficiency of DSSC using active carbon as a catalyst in the reference electrode, produces a larger percentage than black carbon and graphite, which is of $0.05 \%$ for active carbon, black carbon to $0.032 \%, 0.029 \%$ for graphite.

KATA KUNCI: Dye Sesitized Solar Cell, dye, chlorophyll, catalyst http://dx.doi.org/10.12962/j24604682.v13i1.2150

\section{PENDAHULUAN}

Cahaya matahari merupakan salah satu sumber energi alternatif yang bersih, ramah lingkungan, dan aplikatif. Di dunia ini timbul suatu dorongan untuk menciptakan atau merancang suatu sistem untuk penyediaan energi yang aman dan nyaman bagi manusia maupun lingkungan. Cahaya matahari telah banyak digunakan sebagai sumber energi pada sel surya. Sel surya merupakan suatu peralatan yang dapat mengubah energi cahaya menjadi energi listrik. Pengembangan sel surya menjadi sebuah penyediaan energi ketika manusia dihadapkan pada berkurangan cadangan energi yang berasal dari bahan bakar fosil [1].

Akan tetapi penggunaan sel surya sebagai sumber energi listrik masih terbatas karena kendala oleh mahalnya bahan utama dari sel tersebut, yaitu silikon. Namun, setelah melewati perkembangan zaman, teknologi sel surya juga ikut berkembang. Perkembangan tersebut telah sampai pada sel surya yang dikembangkan oleh Grätzel. Sel ini sering juga disebut dengan sel Grätzel atau Dye Sensitized Solar Cells (DSSC) atau sel surya berbasis pewarna tersensitisasi (SSPT)

\footnotetext{
*E-MAIL: nurrisma@physics.its.ac.id
}

[2].

Pada DSSC, selain semikonduktor pada fotoanoda dan elektrolit yang menjaga stabilitas elektron pada siklus DSSC, elektroda pembanding merupakan salah satu faktor penting dalam berlangsungnya siklus terproduksinya arus dan tegangan. Fungsi utama elektroda pembanding adalah sebagai katalis agar proses berlangsungnya transfer elektron dan proses reduksi iodine/triiodide pada elektrolit semakin cepat, dengan demikian semakin cepat pula DSSC memproduksi listrik. Bahan katalis yang sering digunakan sebagai bahan yang dapat mempercepat reaksi redoks pada DSSC adalah katalis dari bahan platina. Namun karena harga platina yang mahal, seringkali bahan katalis pada DSSC diganti menggunakan bahan yang mudah diperoleh dan lebih murah dibandingkan dengan platina, yaitu karbon. Selain itu, karbon mempunyai sifat tahan terhadap korosi dan mempunyai kemampuan elektrokatalitis yang baik terhadap triiodide [3]. Telah banyak penelitian yang mencoba menggantikan peran dari platina dengan bahan karbon seperti black carbon [4-7], karbon aktif [5], single [8] atau multi-wall carbon nanotube [9-11], graphene oxide, maupun reduced graphene oxide [3].

Pada paper ini dilaporkan hasil kinerja pengaruh jenis katalis yang digunakan pada elektroda pembanding terhadap efisiensi DSSC. 


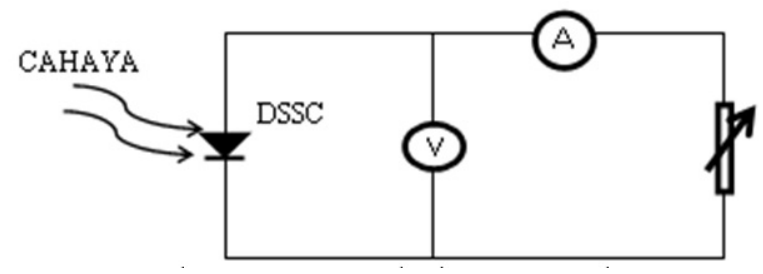

Gambar 1: Rangkaian pengukuran tegangan dan arus.

\section{METODOLOGI}

\section{Sintesis nano partikel $\mathrm{TiO}_{2}$}

Sintesis $\mathrm{TiO}_{2}$ dilakukan dengan metode kopresipitasi. Metode kopresipitasi dilakukan dengan mencampurkan asam dan basa sehingga memperoleh endapan bahan yang diinginkan. Pertama dituangkan aquades sebanyak $100 \mathrm{ml}$ ke dalam gelas kimia yang kemudian ditambahkan $20 \mathrm{ml}$ $\mathrm{TiCl}_{3}$ kemudian diaduk selama 1 jam. Selanjutnya dengan tetap dalam keadaan diaduk, larutan tersebut ditetesi dengan $\mathrm{NH}_{4} \mathrm{OH}$ (Merck) sampai larutan menunjukkan pH 9. Setelah larutan menunjukkan $\mathrm{pH} 9$, penetesan $\mathrm{NH}_{4} \mathrm{OH}$ dihentikan namun larutan tetap dalam keadaan diaduk hingga warna larutan menjadi putih pekat. Kemudian larutan tersebut diendapkan pada temperatur kamar dan tertutup rapat selama 24 jam. Selanjutnya apabila larutan sudah mengendap, maka dilakukan pencucian larutan dengan menambahkan $200 \mathrm{ml}$ aquades. Pencucian diulang kembali sampai didapatkan larutan dengan $\mathrm{pH}$ 7. Setelah diperoleh endapan dengan $\mathrm{pH} 7$, dilakukan kalsinasi dengan temperatur $400^{\circ} \mathrm{C}$ selama 3 jam hingga terbentuk $\mathrm{TiO}_{2}$ dengan fase anatase [12].

\section{Deposisi pasta $\mathrm{TiO}_{2}$ pada kaca ITO}

Pasta $\mathrm{TiO}_{2}$ dibuat dari serbuk nano $\mathrm{TiO}_{2}$ yang dihaluskan terlebih dahulu dalam mortar yang sudah ditambahkan $1 \mathrm{ml}$ aquades selama 10 menit. Kemudian ditambahkan 0,7 ml asam asetat (Merck) dan 0,7 ml triton X-100 (Merck) dan ditambahkan PEG 1000 [13].

Pada sisi kaca ITO berukuran $2 \mathrm{~cm} \times 2 \mathrm{~cm}$ dibentuk area pembatas menggunakan plastik wrapuntuk pendeposisan $\mathrm{TiO}_{2}$ di atas permukaan kaca konduktif yang sebelumnya telah diukur resistansinya. Pasta $\mathrm{TiO}_{2}$ dideposisikan di atas area yang sudah dibentuk dengan metode Doctor-Blade. Setelah itu dilakukan pemanasan di atas hot plate dengan temperatur $450^{\circ} \mathrm{C}$ selama 10 menit.

\section{Pembuatan ekstraksi dye}

Dye yang digunakan pada penelitian ini adalah dye alami yaitu klorofil yang diambil dari daun alfalfa (Medicago Sativa). Proses pembuatan larutan dye klorofil adalah dengan mencampurkan $2 \mathrm{ml}$ klorofil dalam $70 \mathrm{ml}$ aquades. Selanjutnya dilakukan uji absorbansi dengan menggunakan Spektrofotometer UV-Vis. Dilakukan proses perendaman pada dyeselama satu hari. Perendaman dye tersebut juga dilakukan untuk masing-masing variasi polimer pada elektrolit dan katalis yang digunakan.

\section{Pembuatan elektroda pembanding}

Elektroda pembanding pada DSSC berupa kaca dengan permukaan konduktif yang dilapisi oleh tiga jenis karbon, yaitu grafit, black carbon dan active carbon. Fungsi karbon sebagai katalis untuk mempercepat reaksi pada DSSC. Selanjutnya dibuat untuk masing-masing katalis, yaitu 3,5 gr black carbon dilarutkan dalam $15 \mathrm{ml}$ ethanol. Kemudian lapisan elektroda pembanding dipanaskan di atas hotplate pada temperatur $250^{\circ} \mathrm{C}$ selama 30 menit.

\section{Pembuatan elektrolit}

Elektrolit yang digunakan pada DSSC ini berupa elektrolit gel yang berbasis polimer PEG (polyethylene glycol). Pembuatan elektrolit gel yaitu: 7 g PEG (Merck) + 25 ml pelarut + elektrolit cair (3 gram KI yang dilarutkan pada $10 \mathrm{ml}$ acetonitrile (VWR) dan $3 \mathrm{ml}$ larutan iodine). Campuran tersebut diaduk dengan pengaduk magnetik sambil dipanaskan pada temperatur $80^{\circ} \mathrm{C}$ hingga homogen dan membentuk gel [14].

\section{Pembuatan sandwich DSSC}

Lapisan DSSC merupakan susunan dari elektroda kerja dan elektroda pembanding yang disusun flip over menyerupai susunan sandwich yang dimana terdapat elektrolit diantara kedua elektroda. Elektroda kerja merupakan elektroda yang terdiri dari kaca ITO yang dilapisi $\mathrm{TiO}_{2}$ kemudian direndam pada suatu dye.

\section{Karakterisasi}

Hasil sintesis struktur nanokristal $\mathrm{TiO}_{2}$ dikarakterisasi dengan X-Ray diffraction (XRD). Spektrum absorpsi larutan dye klorofil diukur menggunakan UV-Vis Spectrophotometer (Genecys 10S UV-Vis, Thermo Scientific). Karakterisasi arus dan tegangan (I-V) menggunakan alat Keithley I$\mathrm{V}$ meter. Data keluaran dan alat I-V meter merupakan nilai arus dan tegangan. Dari grafik hubungan tersebut dapat diketahui karakteristik sel DSSC yang dibuat dengan menganalisis parameter sel-surya seperti; tegangan open-circuit $\left(\mathrm{V}_{o c}\right)$, arus short circuit $\left(\mathrm{I}_{s c}\right)$, Maximum Power Point (MPP), tegangan dan arus pada MPP (VMPP dan IMPP), fill factor (FF) dan efisiensi. Pengambilan data menggunakan I-V meter dilakukan di Laboratorium Fisika ITB dengan daya 100 $\mathrm{mW} / \mathrm{cm}^{2}$, dengan rangkaian pengukuran seperti ditunjukkan Gambar 1 .

\section{HASIL DAN DISKUSI}

Karakterisasi $\mathrm{TiO}_{2}$ dilakukan dengan alat XRD didapatkan $\mathrm{TiO}_{2}$ berfase anatase dengan ukuran pertikel 11,15 nm (Gambar 2). Hasil pengujian absorbansi dye klorofil dari cahaya dengan menggunakan Spektrofotometer UV-Vis ditunjukkan pada Gambar 3.

Berdasarkan hasil grafik pada Gambar 3 diketahui bahwa dye klorofil memiliki spektrum absorbansi cukup lebar yang berkisar antara 300-700 nm dan mempunyai nilai absorbansi 


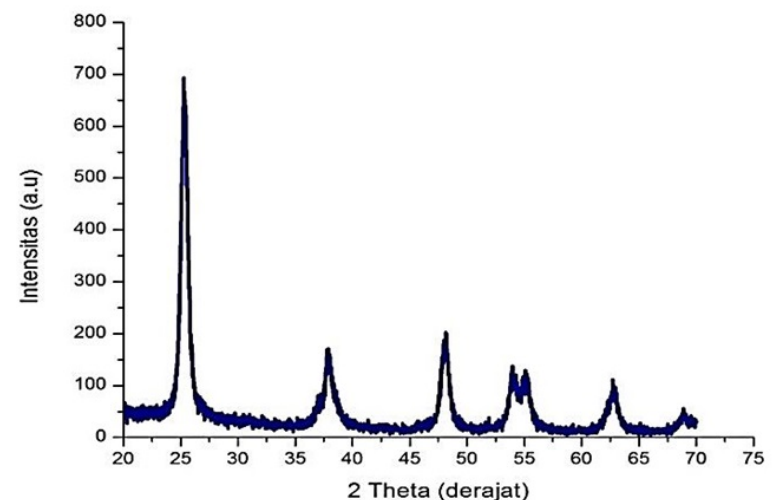

Gambar 2: Hasil pola difraksi sinar x pada serbuk $\mathrm{TiO}_{2}$.

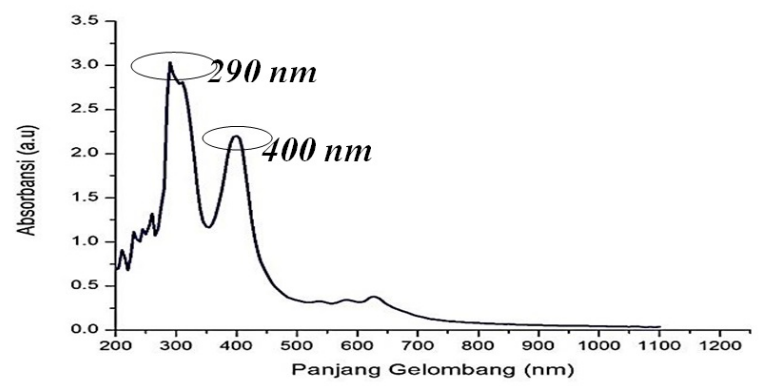

Gambar 3: Spektrum absorbansi dye klorofil.

yang optimum pada panjang gelombang $290 \mathrm{~nm}$ dan $400 \mathrm{~nm}$ yaitu berturut-turut sebesar 3.03 a.u dan 2.2 a.u. Penelitian ini menggunakan lampu Xenon sebagai sumber cahaya pada saat penyinaran DSSC karena intensitas pencahayaannya konstan dan memiliki nilai absorbansi pada rentang panjang gelombang 250-600 $\mathrm{nm}$ yang masih berada pada rentang panjang gelombang cahaya tampak [15], sehingga dengan nilai absorbansi tersebut, dye klorofil dapat dikatakan mempunyai nilai absorbansi yang baik. Nilai efisiensi DSSC bergantung juga pada absorbansi panjang gelombang yang digunakan. Semakin lebar spektrum absorbansi dye klorofil, maka semakin banyak frekuensi cahaya yang dapat diserap oleh sel surya.

Hasil karakterisasi SEM pada katalis ditunjukkan pada Gambar 4. Gambar 4 menunjukkan top view SEM dari elektroda active carbon (AC), black carbon (BC) dan grafit. Gambar tersebut menunjukkan bahwa bentuk partikel dari seluruh sampel adalah partikel berbentuk bulat. Pada hasil uji SEM terlihat bahwa permukaan lapisan active carbon lebih berpori dan seragam jika dibandingkan dengan lapisan black carbon dan grafit. Struktur permukaan yang berpori sangat diharapkan pada lapisan elektroda ini, karena dengan struktur yang berpori akan lebih banyak elektron yang ditangkap dari rangkaian luar dan memungkinkan elektron lebih cepat diterima oleh elektrolit. Dengan demikian proses transfer elektron dan siklus redoks pada elektrolit semakin cepat, sehingga arus foto yang dihasilkan menjadi lebih besar. Selain itu, morfologi elektroda black carbon dan grafit menunjukkan aglom-

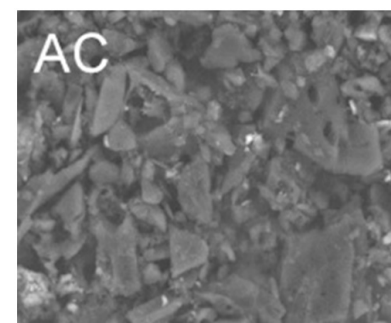

(a) active carbon (AC)

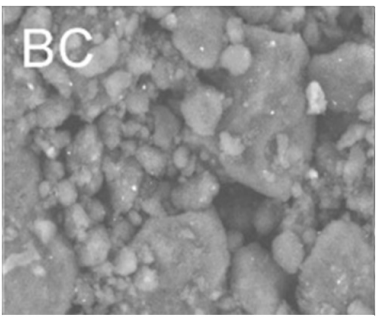

(b) black carbon (BC)

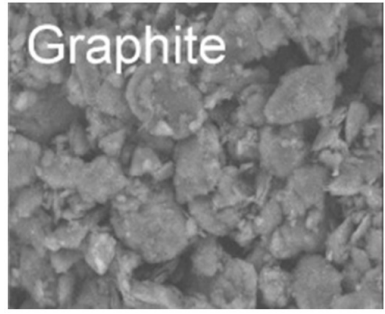

(c) grafit

Gambar 4: Hasil karakterisasi uji SEM pada katalis.

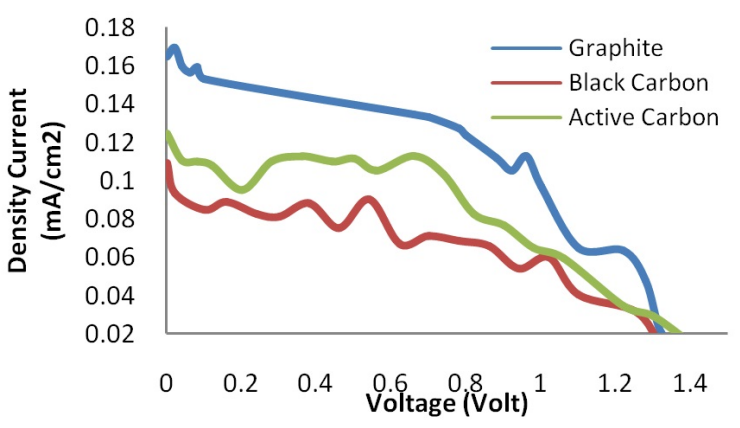

Gambar 5: Hasil karakterisasi I-V DSSC variasi katalis.

erasi yang sedikit besar dan homogen. Aglomerasi ini menurun kontak listrik karena menyebabkan adanya resistansi semakin besar serta proses transfer elektron menjadi lebih lambat dan berpengaruh pada performa dari DSSC.

Pada hasil karakterisasi I-V untuk variasi katalis, efisiensi DSSC menggunakan katalis active carbon lebih tinggi dibandingkan dengan DSSC yang menggunakan black carbon dan grafit sebagai katalisnya. Hasil karakterisasi dapat dilihat pada Tabel I.

Pada DSSC ini, tegangan dan arus yang dihasilkan juga tidak jauh berbeda, akan tetapi faktor pengisian pada DSSC ini menunjukkan perbedaan yaitu faktor pengisian untuk $a c$ -

TABEL I: Hasil karakterisasi DSSC dengan variasi katalis.

\begin{tabular}{ccccc}
\hline \hline $\begin{array}{c}\text { Nama } \\
\text { Sel }\end{array}$ & $\begin{array}{c}\text { VOC } \\
\text { (Volt) }\end{array}$ & $\begin{array}{c}\text { ISC } \\
\left(\mathrm{mA} / \mathrm{cm}^{2}\right)\end{array}$ & $\begin{array}{c}\text { FF (\%) } \\
(\%)\end{array}$ & $\begin{array}{c}\eta \\
(\%)\end{array}$ \\
\hline & & & & \\
Grafit & 1,382 & 0,160 & 13,2 & 0,029 \\
Black Carbon & 1,402 & 0,109 & 21,4 & 0,032 \\
Active Carbon & 1,401 & 0,124 & 28,5 & 0,05 \\
\hline \hline
\end{tabular}


tive carbon lebih besar jika dibandingkan dengan dua katalis lainnya.Hasil efisiensi dari ketiga katalis berbading lurus dengan factor pengisiannya. Hal ini dapat disebabkan karena morfologi dari masing-masing katalis yang berbeda. Morfologi permukaan masing-masing katalis dapat ditunjukkan pada hasil karakterisasi SEM. Grafik hasil karakterisasi I-V untuk variasi katalis dapat dilihat pada Gambar 5.

\section{SIMPULAN}

Prototipe DSSC telah berhasil dibuat dan dapat mengkonversi energi cahaya menjadi listrik. Hasil efisiensi DSSC un- tuk katalis dari bahan active carbon nilainya lebih besar jika dibandingkan dengan black carbon dan grafit, yaitu 0,005\% untuk active carbon, $0,032 \%$ untuk black carbon, dan $0,029 \%$ untuk grafit.
[1] D. Almanda, Prospek PLTS di Indonesia, majalah elektro indonesia, edisi ke-10 (1997).

[2] Oregan, and M. Grätzel, Nature, 353(6346), 737-740 (1991).

[3] R. Cruz, et al., Solar Energy, 86(2012), 716-724 (2011).

[4] T. Kitamura, et al., Chemistry Letters, 30, 1054-1055 (2001).

[5] Imoto, et al., Solar Energy Materials and Solar Cells, 79, 459469 (2003).

[6] T. Murakami,et al., Journal of The Electrochemical Society 153, A2255A2261 (2006).

[7] T. Murakami, and M. Grätzel, Inorganica Chimica Acta, 361, 572-580 (2008).

[8] K. Suzuki, et al., Chemistry Letters 32, 28-29 (2003).

[9] E. Ramasamy, et al., Electrochemistry Communications, 10, 1087-1089 (2008).
[10] S.I. Cha, et al., Journal of Materials Chemistry, 20, 659-662 (2009).

[11] C.-S. Chou, et al., Advanced Powder Technology, 20, 310317 (2009).

[12] H.N. Widaryanti, H., Pembentukan Nanopartikel $\mathrm{TiO}_{2}$ Fasa Anatase dan Rutile dengan Metode Bervariasi, Skripsi, FisikaITS, Surabaya, 2010.

[13] L.J. Kook, et al., Journal of Industrial and Engineering Chemistry, 15, 724-729 (2009).

[14] A. Maddu, M. Zuhri, dan Irmansyah, Makara, Teknologi, 11(2),78-84 (2007).

[15] H. Sastrohamidjojo, Spektroskopi Inframerah (Liberty Yogyakarta, Yogyakarta, 1992). 